\title{
Biomass Energy in Malaysia: Current Scenario, Policies, and Implementation Challenges
}

\author{
Nor Adilla Rashidi ${ }^{1}$ (D ) Yee Ho Chai ${ }^{1}$. Suzana Yusup ${ }^{2}$
}

Received: 11 October 2021 / Accepted: 7 January 2022 / Published online: 21 January 2022

(c) The Author(s), under exclusive licence to Springer Science+Business Media, LLC, part of Springer Nature 2022

\begin{abstract}
The energy demand in Malaysia has shown a dramatic increase over the last few years: with natural gas and coal being the primary contributors. Nevertheless, due to declining in fossil fuel reserves coupled with negative environmental impacts, shifting to sustainable renewable energy for meeting the future energy demand is recommended. Since Malaysia is rich with natural resources, utilization of biomass energy (bioenergy/biofuel) as the alternative energy is promising to be further explored. Therefore, this review paper intents to discuss the current scenario of different types of biomass energy in Malaysia along with the up-to-date local biomass energy-related environmental policy (from 2016 onwards). In addition, challenges and barriers for large-scale implementation of the biomass energy in Malaysia are to be discussed. Overall, this review paper is interesting as it can assist in promoting the biomass utilization as energy source, and to ensure the future growth of biomass energy market in the country along with its effective implementation while alleviating poor disposal problem and to create job employment opportunities. Furthermore, a collective effort to expand potential biomass feedstocks, apart from oil palm, should be emphasized to encourage the renewable energy production diversification in the nation.
\end{abstract}

Keywords Bioeconomy $\cdot$ Bioenergy production $\cdot$ Bioenergy policies $\cdot$ Bioenergy outlook $\cdot$ Malaysia renewable energy

\section{Introduction}

Global energy demand in the twenty-first century is currently witnessing a substantial growth of demand that is coupled with increasing energy-intensive productions, to meet the ever-growing needs of consumer populations. Since the First Industrial Revolution in 1784, fossil fuels, namely coal, oil, and gas, have continued to play a pivotal role in the provision of global energy demand albeit its detrimental effects towards the environment. As a global oil and gas producer, the energy sector in Malaysia is heavily dependent on conventional fossil fuel resources, where $88.4 \%$ constitutes

Nor Adilla Rashidi

adilla.rashidi@utp.edu.my

1 HICoE - Centre for Biofuel and Biochemical Research, Institute of Self-Sustainable Building, Department of Chemical Engineering, Universiti Teknologi PETRONAS, 32610 Seri Iskandar, Perak, Malaysia

2 Generation Unit (Fuel \& Combustion Section), Tenaga Nasional Berhad Research (TNBR), No 1, Kawasan Institusi Penyelidikan, Jln Ayer Hitam, 43000 Kajang, Selangor, Malaysia fossil fuels and can be further broken down to account for $53.3 \%$ natural gas, $30.5 \%$ coal, $2.8 \%$ fuel oil, and $1.8 \%$ diesel [1], while the remaining are contributed by hydropower. In 2016, electricity generated by fossil fuel-based thermal plants remained dominant at $83.2 \%$ compared to hydropower at $12.8 \%$ [2], thus highlighting its continued dependency as main resource for the energy generation [3].

Nevertheless, the current world energy development scene is transitioning into a new period, where low-carbon emission, clean and environmental-friendly characteristics have been prioritized for the generation of energy. Based on the report by the International Renewable Energy Agency (IRENA) [4], the global renewable energy generation capacity amounted to $2,537 \mathrm{GW}$ with $7.4 \%$ growth as of 2019 , as compared to previous year. Referring to Tock et al. [5], selection of appropriate renewable energy in any country depends on three factors, geographical location, climate condition, and availability of renewable resources. Thus, in local context where Malaysia is blessed with tropical and humid climate for agricultural and forest plantation, biomass energy (bioenergy) utilization is a formidable underlying potential that can be capitalized to develop the local renewable energy scene in Malaysia and as an option to reduce greenhouse 
gas (GHG) emission by $45 \%$ of the nation's GDP by 2030 [6]. Unlike fossil fuel, biomass production and utilization are promising due to net carbon dioxide $\left(\mathrm{CO}_{2}\right)$ emission, since released $\mathrm{CO}_{2}$ during power generation will be compensated by the $\mathrm{CO}_{2}$ consumption in photosynthesis process $[5,7]$. Referring to recent assessment done by Stougie et al. [8], environmental sustainability of the biomass energy is indeed lower as compared to coal-fired power plant (12 vs. $19 \mathrm{MPt}$ ). Herein, bioenergy is a form of renewable energy generated from biomass sources via traditional and modern approaches, where traditional techniques rely on combustion of biomass to generate energy while modern technologies involve liquid biofuel production, biogas generation by anaerobic digestion, or bio-refineries as illustrated in Fig. 1. Furthermore, production of bioenergy is obtainable in the form of agricultural and wood processing wastes, residues, and forest products such as logging residues [9]. As the fourth largest resources around the world, the adaptation of biomass to energy source is prospective as it is distinctively abundant in nature and can be easily generated in non-urban settings in Malaysian context [10].

Thus, the paper outlines current status of bioenergy deployment in Malaysia, specifically biodiesel fuel and valorization of biomass towards the emerging bioethanol and biogas sectors. The paper seeks to compare current local policies (short- and long-term) with respect to the countries with successful bioeconomy frameworks implementation like Finland and Sweden, as well as neighbouring tropical countries with similar aspirations such as Thailand and Indonesia as benchmarking study. Lastly, this review paper explores the trilemma factors with respect to the pillars of sustainability for amelioration of biomass energy implementation and mitigation at the local context setting.

\section{Malaysian Biomass Energy: Industrial Status and Development}

The oil palm industry is a leading contributor of biomass in Malaysia; hence, it has a great prospect to be commercialized for bioenergy production [11, 12]. To date, bioenergy particularly palm biodiesel has emerged as a potential sustainable and eco-fuel in Malaysia [13], due to its resemblance with the conventional diesel with respect to chemical structure and energy content, low sulphur content, non-toxicity, and high biodegradability, as well as good combustion efficiency [14, 15]. In fact, Li and Loo [16] reported that Malaysia is indeed the primary biodiesel producer, aside from the USA, France, Brazil, India, Indonesia, and Australia. On top of that, Malaysian palm biodiesel for transportation has been accepted by the Japan Automobile Manufacturers Association (JAMA) where it can be used up to $20 \%$ biodiesel blend. Referring to the Malaysian Palm Oil Board (MPOB), local biodiesel demand increased to

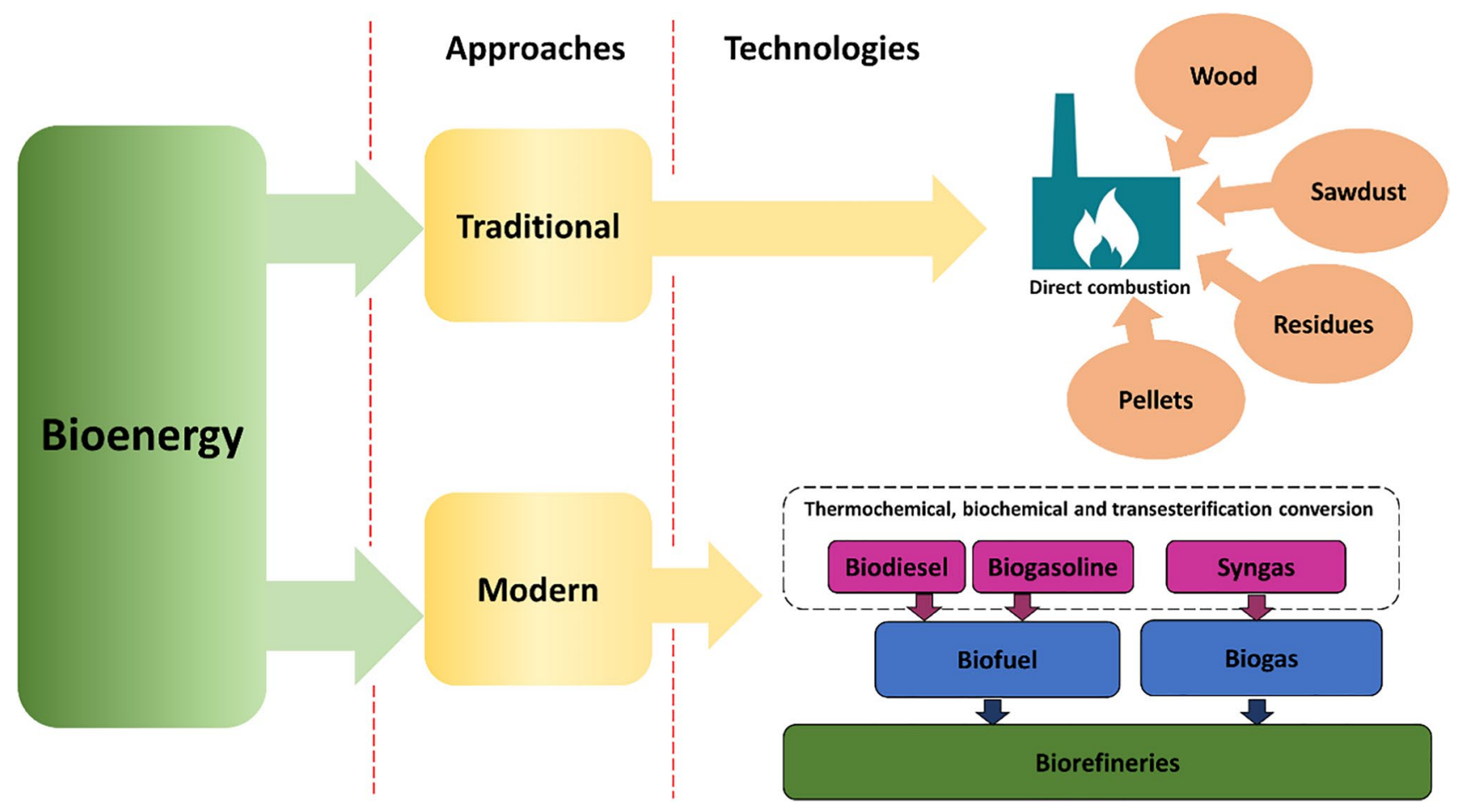

Fig. 1 Typical roadmap of bioenergy production 
529,000 tonnes in October 2019 and surpasses the initial estimation of 520,000 which is attributed to the enforcement of B10 biodiesel programme in February 2019 for the transportation sector, as well as B7 biodiesel for the industrial sector. In addition, Gan and Li [17] reported that the exploitation of palm biodiesel has been projected to reach up to 0.4 million tons by 2035 . Considering the various environmental benefits of biodiesel as fuel replacement, Malaysia is currently gearing up towards the implementation of biodiesel B20 for transportation while B10 for the industrial sector. As of in 2017, there are about 17 biodiesel plants in operation with total installed capacity of 2.05 million tonnes of biodiesel per annum [18]. The chronology of biodiesel industry in Malaysia is as per described in Table 1. In Malaysia, MPOB is the leading governmental agency that is responsible for the construction of commercial biodiesel plant with capacity of 60,000 tonnes per annum, as well as continuous research and development (R\&D) activities towards the development of new technologies for palm biodiesel as well as winter-grade palm biodiesel [19].
Apart from biodiesel production, biomass conversion to bioethanol is also a promising sector. While biodiesel is used as a substitute for conventional diesel fuel, bioethanol can be used as a replacement for gasoline and fossil petrol [24]. However, unlike the biodiesel, bioethanol has not been emphasized in the country $[25,26]$. It has been reported that Malaysia does not have the bioethanol programme due to lacking in domestic feedstock; hence, it is infeasible to implement a renewable programme that heavily relies on imported feedstock, regardless of various benefits of this renewable energy. Comparing with Thailand and Philippines that are the leaders in bioethanol production amongst the Southeast Asia countries, the plantation area of bioethanol feedstock (i.e. cassava, maize, rice, sugarcane, and sweet potato) as well as the corresponding yield is relatively low [27]. Moreover, Kumar et al. [28] reported that the slow evolution of bioethanol in Malaysia is attributed to the high cost of sugar-rich substrates (e.g. sugarcane) while production from starchy crops such as sago and sweet sorghum has not been commercialized yet. Due to these limitations, Tye et al. [26] reported that the bioethanol industry in Malaysia

Table 1 Evolution of the biodiesel industry in Malaysia [20-23]

\begin{tabular}{|c|c|}
\hline Timeline & Milestones \\
\hline 1981 & Malaysian Palm Oil Board (MPOB) started the first biodiesel project (January) \\
\hline 1982 & Initiation of laboratory research on palm methyl ester (PME) biodiesel \\
\hline 1983 & Establishment of Palm Diesel steering committee by the Ministry of Primary Industries \\
\hline 1984 & $\begin{array}{l}\text { Construction/commencement of the first PME biodiesel plant in collaboration with PETRONAS, with total capacity of 3,000 } \\
\text { tonnes per annum }\end{array}$ \\
\hline 1984-1985 & Preliminary field trial: 8 taxis \\
\hline 1986-1989 & Field trial (phase 1) involving 31 diesel-powered vehicles and stationery engines \\
\hline 1990 & Field trial (phase 2): bench test by Mercedes Benz in Germany \\
\hline 1990-1994 & Field trial (phase 3 ) involving 36 commercial buses \\
\hline 1992 & $\mathrm{R} \& \mathrm{D}$ on winter grade biodiesel production technology \\
\hline 1995 & $\begin{array}{l}\text { Establishment of palm biodiesel as substitute for diesel, transfer of the PME technology to other industries, i.e. oleo-chemical, } \\
\text { carotenes, vitamin E }\end{array}$ \\
\hline 2000-2002 & Construction of the first commercial biodiesel power plant by Carotino Sdn. Bhd \\
\hline 2001 & Initiation on the use of crude palm oil and oil blend for power generation, R\&D of low-pour-point palm biodiesel \\
\hline 2002 & Initiation of field trials of processed liquid palm oil and biodiesel blend (B2, B5, B10) in MPOB vehicles \\
\hline 2004 & Series of trials of refined, bleached, and deodorized (RBD) palm oil and palm biodiesel blend (B5) in MPOB vehicles \\
\hline 2005 & $\begin{array}{l}\text { MPOB technology transfer to Lipochem (M) Sdn. Bhd. and Carotino Sdn. Bhd. for the construction of PME biodiesel plants, } \\
\text { development of the first biodiesel refinery in Labu, Negeri Sembilan, design of commercial low-pour-point biodiesel plants }\end{array}$ \\
\hline 2006 & $\begin{array}{l}\text { Launching of the world's first integrated palm biodiesel plant at Carotino Sdn. Bhd. and two other plants using the MPOB tech- } \\
\text { nology, introduction of Envo Diesel (5\% of RBD palm olein biodiesel), approval of } 92 \text { biodiesel projects }\end{array}$ \\
\hline 2008 & Establishment of Malaysian Biodiesel Association, cancellation of Envo Diesel programme \\
\hline 2009 & Replacement of palm olein with palm methyl ester, more than 3,900 vehicles from the various agencies conducted the field test \\
\hline 2011 & Official launching of B5 programme (for transportation) \\
\hline 2014 & $\begin{array}{l}\text { Full implantation of B5 programme in Peninsular Malaysia (March), commencement of B7 programme (for transportation) in } \\
\text { Peninsular Malaysia (November) }\end{array}$ \\
\hline 2015 & Implementation of B7 programme in Sabah and Sarawak \\
\hline 2019 & Implementation of B7 programme in industrial sector and B10 in transportation sector \\
\hline 2020 & Launching of the national B20 biodiesel programme for transportation sector \\
\hline
\end{tabular}


is new and accordingly has not much experiences. Therefore, instead of being the producer, Malaysia has been projected to be amongst the major importer of bioethanol commodity (11 million litres) [29]. However, Szulcyzk et al. [30, 31] predicted that the palm oil industry has the potential to produce up to 7.2 billion litres of bioethanol by 2023. Therefore, further studies will be needed as the technology is still in experimental stage and not yet being commercialized. Once this type of bioenergy has been commercialized, it will be feasible for the Malaysian government to establish the bioethanol policy. To start, ethanol blends of less than E15 could be introduced as car manufacturers do not need to modify the gasoline engines, and subsequently to raise the mandates.

In addition, biogas as potential biomass energy is gradually emerging in Malaysia. It has been reported that the potential of biogas industry can reach to RM 8.3 billion (USD 2.3 billion) by year 2022, possibly contributed by different biomass sources including agricultural waste, crop residue, animal manure, domestic and household waste, amongst others [32]. Nevertheless, the installation of biogas plants in Malaysia is rather slow as compared to solar photovoltaic (PV) as well as mini hydro [33]. Based on the Sustainable Energy Development Authority (SEDA) statistics, the cumulative installed capacity of commissioned biogas plants in Malaysia from year 2012-2019 is about $102.77 \mathrm{MW}$ : equivalent to $16 \%$ of the total renewable energy in Malaysia. The biogas production is harvested through two methods - landfill gas and anaerobic digestion (palm oil mill effluent (POME)) [33, 34]. In context of landfill gas, this approach that is most commonly used for the biogas production is promising due to high availability of municipal solid waste in Malaysia, which is often dumped in non-sanitary landfills [33, 34]. At present, the solid waste in Malaysia has been estimated to be around 33,130 tonnes per day and increased to 49,670 tonnes per day by 2030 [35]. Meanwhile, the second technique that uses the POME for biogas production is attributed to its abundance at the oil palm mills. In addition, POME characteristics that are not in accordance to the Department of Environment make it susceptible for biogas production [36]. Basically, 1 tonne of POME is capable to generates $28 \mathrm{~m}^{3}$ of biogas; and 2.4 tonnes per annum of methane gas produced is equivalent to 3.4 million litres of diesel [37]. With this respect, the biogas trapping from POME feedstock is significant, as supported by the National Key Economic Area (NKEA) - Entry Point Project $5[33,38]$. Under this programme, MPOB has been appointed as the implementing agency while the progress is regularly monitored by the MPOB NKEA Biogas Working Group, and to be reported to the NKEA Palm Oil and Rubber Steering Committee led by the Minister of Plantation Industries and Commodities. The role of Biogas Working Group is to coordinate, facilitate, monitor, and review the programmes on biogas implementation in palm oil mills.
Besides, the working group is responsible in identifying the barrier for successful implementation and to formulate and propose the action plans $[36,38]$. To date, produced biogas from POME is used for combined heat and power (CHP) for steam and electricity production, steam generation, electricity generation, and downstream business technologies [38]. Nevertheless, Yusoff et al. [39] claimed that the use of POME for biogas production via an anaerobic digestion is not environmentally friendly since the process may release $\mathrm{CO}_{2}$ to surroundings. Similarly, Choong et al. [40] reported that anaerobic process of POME through a low-cost anaerobic system suffers from extensive large area required and escaping GHG to the atmosphere. Thus, Yusoff et al. [39] proposed to utilize POME as a potential substrate for biodiesel production via pyrolysis, transesterification, supercritical, microwave-assisted ultrasound, etc.

Further, bio-hydrogen as parts of biomass energy also plays a significant role. Referring to Mah et al. [41], the bio-hydrogen from the biomass is the backbone of hydrogen economy due to its sustainability and environmentalfriendly properties. Besides, cost of hydrogen production from biomass pathway is significantly lower (\$1.25-2.83/ $\mathrm{kg}$ ) as compared to electrolysis [42]. However, it has been reported that the hydrogen production from agricultural residues (including palm biomass) is relatively small and has not been commercialized yet [43, 44], though Mah et al. [41] reported that biomass pathway is expected to be commercially available in the mid-term. Basically bio-hydrogen can be produced either from thermo-chemical approach (i.e. biomass pyrolysis, gasification) or biological approach (fermentation, bio-photolysis, and biological water-gas shift reaction) $[45,46]$. While the biological conversion involves the uses of enzymes, bacteria, or microorganism, the thermochemical conversion involves the breakdown of biomass by applying heat and through chemical interactions [47]. In addition, when comparing these two options, thermochemical technique is said to be more feasible due to its simpler route, faster and higher stoichiometric yield, no addition of chemical, and capable to convert a variety of wet biomass feedstock $[48,49]$. On the other hand, the biological conversion which is performed under mild conditions is said to be more environmental-friendly and less energy intensive, despite its low rates and yield ( $\mathrm{mol} \mathrm{H}_{2} / \mathrm{mol}$ feedstock) [49, 50]. Therefore, further development on the bio-hydrogen production from the oil palm biomass will be anticipated.

\section{Biomass Energy-Related Environmental Policy}

In this section, the current existing biomass energy-related environmental policies and its associated development in Malaysia are outlined and discussed. In addition, the policies 
adopted by Finland and Sweden, which have been identified by the International Energy Agency (IEA) as the top two countries with regard to total primary energy supply by bioenergy per capita [51], as well as the neighbouring tropical countries such as Indonesia and Thailand are also included.

\section{Finland}

Renewable bioenergy programmes are notably supported in 1979 when the first Energy Programme was introduced. This was partly due to the geographical locations such as cold temperature climate requiring increased heating energy, sparse population that made up for energy demand of transport, and energy-intensive processing industries, as well as the predominant concept of energy economy [52].

The tabulated energy policy in 1979 accounted for $\mathrm{CO}_{2}$ tax, promotion of renewable energy sources, and taxation of fossil fuel-based resources. Furthermore, Finland had viewed national technology development as necessary with differing R\&D monetary allocations from the IEA countries. For example, monetary allocations hugely focused towards efficient energy use, bioenergy, and national power programmes [52]. Notwithstanding, early initiation of a carbon-based tax introduced in 1990 allowed a favourable progression on biomass utilization as the renewable energy resource. Carbon tax in Finland at 2002 was $17.2 \mathrm{€h} /$ tonne $\mathrm{CO}_{2}$ in addition to special refund incentives allocated for the energy-intensive industries [53]. In addition, the investment supports are also allocated by the Finnish government for peat and biomass-based heat and power plants amounting to $10-25 \%$ of the investment cost [54]. Subsidy equivalent to the Finnish electricity tax is also provided for the biomass-based electricity production plants [53]. These basically have been supported by Berg et al. [55], who reported that the bioenergy policy in Finland mainly focuses on the R\&D and investment support, energy, tax exemptions, and rebates, as well as information provision, with a gradual modification over the years in order to target specific bioenergy sources.

In addition, Åkerman et al. [56] highlighted the concepts of forestry institutionalization framework as a large technological system for the large-scale utilization of its natural resources. In response, specific policy concepts promote the bioenergy production by utilizing the existing "biomass reserves", which is a conceptual tool to evaluate the readily available forest resource to harness maximum energy potential, in order to avoid disruption to the existing forest industry [57]. Furthermore, the Finnish national bioenergy governance is influenced by the forestry interests to competitively positioning itself to avoid weakening of pulp and paper mills, while simultaneously focusing on investment of the bioenergy production via bio-liquid and biofuel products [58].
More recently, Finland had outlined the National Energy and Climate Strategy 2030 to systematically achieve $80-95 \%$ reduction in GHG emissions by 2050 [59]. This strategy aims to completely phase out the use of coal for energy by 2029 , while share of transport biofuels will be further increased to $30 \%$. In addition, electricity production from forest biomass will be subsidized via current Fit-in-Tariff (FiT) until emission allowance by bioenergy is favourable over fossil-based fuel [60]. Overall, the initiatives by Finland to impose high level taxation of fossil fuels and the provision incentives had made the bioenergy generation from biomass resources approaching viable production costs. Lastly, forestry interests also play a great role in contributing towards better bioenergy policy growth in Finland.

\section{Sweden}

In terms of geography, climate, and industrial features, both Sweden and Finland are intrinsically comparable to one another. Like Finland, the policy and governmental initiatives were mainly adapted based on the Paris Climate Accord as well as the European Union (EU) 2030 Climate and Energy Framework. The EU framework strategy aims to reduce domestic emission to $40 \%$ by 2030 and to increase renewable energy utilization by $27 \%$ at the minimum [61]. Several other strategies such as EU Forest Strategy and the land-use and forestry proposal for 2001-2030 (LU-LUCF) were also introduced [62, 63]. In response, Sweden has positioned itself as an important contributor towards the European bioenergy market [64], due to its lush forest residues with 23 million hectares of productive forest land. As of 2012, the overall renewable energy supply in Sweden surpassed the allocated target of $49 \%$ proposed by the EU Renewable Energy Directive (20,009/28EC) and the overall renewable energy target of 50\% set by Swedish government [65]. The development of bioenergy policies in Sweden is rather stable due to promotion of renewable energy source for heat during the late 1970s through the introduction of incentives and carbon tax imposition. Table 2 summarizes the timeline of important tax and incentive measures that had been introduced in Sweden.

Furthermore, to realize the bio-economy status in Sweden, the Swedish government had consolidated additional policies and governmental bills such as net zero emission of GHG by 2045 , and achieving $100 \%$ renewable electricity production by 2040 that are inclusive of existing bioenergy resources [66]. For instance, Jämtkraft, an energy company located in Östersund, utilized return wood, peat, forest, and logging residues as biomass resources that accounted for 99\% of the fuel source required to operate CHP plant in 2014 [67]. In addition, the Green Highway initiative was also another strategy formed by the partnership between Sweden 
Table 2 Key taxes and incentives introduced in Sweden [65]

\begin{tabular}{ll}
\hline Year & Incentives/taxes \\
\hline 1970 s & Presentation of energy taxes to decrease dependence on oil \\
1977 & Proposition of law on municipal energy planning \\
1991 & Introduction of carbon tax \\
$1991-1995 ; 1997-2003$ & Provision of investments to build biomass-based combined heat and power (CHP) \\
$2000-2004$ & Increase in carbon tax and lower in labour tax \\
$1998-2012$ & Local investment programmes for municipalities \\
2002 & Landfill ban for combustible waste \\
2003 & Green certificate scheme to promote new renewable energy electricity production \\
2005 & Landfill ban for organic waste \\
2007 & Tax exemptions for biofuels for transport for use in 2013 \\
2012 & Introduction of Electricity Certificates Act to raise renewable electricity by 26.4 \\
& TWh by 2020 \\
2016 & Framework agreement for net zero emissions to the atmosphere by 2045 \\
\hline
\end{tabular}

and Norway that aims to eliminate the fossil-fuel transportation and to promote renewable fuel-derived fuelling stations along the highway [68]. In this project, raw materials for the renewable fuels consist of waste and by-products from the aquaculture and forestry sectors were utilized.

With the proposition of a low-carbon-based bio-economy policies, an increase in biofuel demands is seen in exchange of biodiversity preservation and protection. Therefore, annual harvest levels should never exceed the annual growth and actions taken to regenerate the forest after each harvest are mandatory. A critical analysis reported by de Jong et al. [69] had shown a conditional dependency within the framework of current advisory specifications by the Swedish Forest Agency, where unfulfillment of conditions such as ash recycling, nutrient compensation, and good general environmental considerations may impede the Environmental Quality Objectives' achievements. Thus, both landscape management and planning are significantly crucial in this process.

\section{Indonesia}

Being one of the most populated developing countries in the Southeast Asia region, the upturn in the economic growth of Indonesia has been a key indicator for domestic energy consumption, with average energy growth rates of $3.93 \%$ annually [70]. To cope with the rising energy demand, Indonesia would require increasing the coal resources utilization up to $33 \%$ of its energy mix by 2025 [71], and accordingly will result in an immense increase in GHGs pollutant emission to the atmosphere as well as its associated environmental problems. As of 2010, the national energy mix in Indonesia consisted of $96 \%$ fossil fuel-based energy supply with a prediction of nearly threefold of the total energy demand in 2025 as compared to 2010 [72]. However in 2013, the total dependency on fossil fuels was reduced to $86 \%$, due to the enforcement of proactive policies to encourage the use of biodiesel with $5.57 \%$ consumption in the same year [73].

With the heavy demand in fossil fuel-based energy resources, the National Energy Policy (Presidential Regulation No. 5/2006) had targeted less than $83 \%$ fossil-based resources consumption, while the bio-fuel energy that constituted $5 \%$ of the remaining portions was comprised of various renewable energy resources [72]. To further reduce the GHG emission, an update to the National Energy Policy was laid out by the Government Regulation No. 79/2014, ensuring $23 \%$ of the total energy demand in Indonesia are covered by the renewable energy by 2025 [74]. Nevertheless, the National Energy Policy that was tailored for a rapid biofuel development programme in Indonesia has resulted in extensive deforestation activities to meet the growing demand of biofuel. As reported by Purnomo et al. [75], the total oil palm plantation area in Indonesia occupies about 14 million hectares. Therefore, to ensure the sustainable production of palm oil for biofuel production, the oil palm plantations in Indonesia are required to comply with the Indonesian Sustainable Palm Oil scheme, involving a strict compliance in ensuring sustainable business development, as well as in environment management and monitoring.

Apart from the National Energy Policy, the National Biofuel Development Team (Timnas BBN) was responsible to create a blueprint and roadmap for the biofuels development in Indonesia and was completed in 2008. This blueprint basically served as a guidance to define Indonesia's biofuel blending targets. Following that, Indonesia's Ministry of Energy and Mineral Resources (MEMR) had issued a regulation (MEMR Regulation 32 2008) to define the minimum biofuel blending over 2008-2025 timeframe for use in transportation, and industrial and commercial use, as well as in electricity generation [74]. Several revisions were made on the regulation, with the 
latest regulation (MEMR Regulation 12 2015) being to enforce $30 \%$ biodiesel blending by 2025 [76]. In the latest development, the programme was given mandate to raise the biofuel blending mix by $30 \%$ at the end of 2019 , while blending mix of $40 \%$ was delayed to 2022 due to world oil crash caused by the coronavirus pandemic [77].

Other noteworthy regulations and policies related to Indonesia's biofuel development include Energy Law (Law Number 30/2007) for the regulation of supply and use of renewable energy with biofuel being one of them, and vehicle emission regulation (Decree of Minister of Life Environment No. 04/2009) to reduce the limit of vehicle admission in Indonesia based on Euro 2 fuel [73, 78]. In addition to its huge agricultural potential in Indonesia, effective government policies are also the driving factors for the R\&D in the biofuel production.

\section{Thailand}

Besides Indonesia, Thailand is also one of the Southeast Asian countries that heavily rely on its agricultural activities as the country's economy backbone [79]. In fact, Thailand is currently amongst the global exporters of major economic crop, notably rice (11 million hectares), natural rubber (3.66 million hectares), and sugarcane (1.96 million hectares) [80, 81]. Further, in context of the bioenergy deployment in Thailand, the first National Alternative Energy Development Plan (2004-2011) had given biofuels mandate for production, taxations and non-tax incentives, R\&D support, and promotion of public awareness [82]. Accordingly, this had led to the encouragement in the demand for E10 premium gasoline (10\% ethanol blended with $90 \%$ gasoline) in 2004 , followed by an insignificant demand in E85 gasoline in 2008 [83]. For biodiesel, the Thai government had introduced the first commercial use of biodiesel for vehicles in Thailand through the promotion of B2 fuel amongst small bus drivers in 2004 and B5 in gas stations in 2008 [84]. Subsequently, the Ministry of Energy, Thailand, had introduced the Renewable Energy Development Plan Master Plan (REDP: 2008-2022) in 2008 to integrate the national alternative energy masterplan that focused on the energy security, balanced economy, and reduction in negative consequences to both environment and community.

In 2012, the Thai government had revised REDP: 2008-2022 to align the nation towards "Low-Carbon Society" and to develop the Alternative Energy Development Plan (2012-2021). The objective of this revised plan basically was to promote the utilization of renewable energy, constituting largely of bioenergy supply, which accounted for $25 \%$ of its total energy consumption by 2021 [83]. Under this plan, biomass, biogas, and municipal solid waste were expected to increase up to 12 times as compared to its existing capacities. The plan was divided into three different phases ranging from short-term to long-term as follows:

1. Short term (2008-2011): emphasis on commercial renewable energy technologies from biofuel, biomass, and biogas energy resources.

2. Medium term (2012-2016): emphasis on the renewable energy technologies, encouragement of the economically viable renewable energy technology and sources, as well as "Green City" concept to encourage communities towards the sustainable energy utilization.

3. Long term (2017-2022): enhance the renewable energy technologies and extension of "Green City" concepts to nationwide and ASEAN countries.

Nevertheless, due to the failure to achieve the shortterm targets, the plan was revised again in 2013 to push the renewable energy target further to $30 \%$ from $25 \%$ by 2036 , between year 2015-2022 timeframe. Herein, both biodiesel and bio-alcohol are expected to play a pivotal role under the revised plan [85]. Furthermore, the key findings by IRENA had shown Thailand's potential in increasing its share of the renewable energy to as high as $37 \%$ from the present $30 \%$ target in 2036 [86].

Overall, continuous investment in the bio-economy development in Thailand, built over the last 20 years, has provided better options compared to its neighbouring countries especially in the bioenergy sector. To further support the bioeconomy development in Thailand, the National Biotechnology Framework 2012-2021 had been developed to foster human capitals in the biotechnology field: in the form of research funding and scholarships [87]. Accordingly, an integrated framework that consists of $R \& D$ activities in renewable energy, i.e. bioenergy and public support of renewable energy production technology, as well as improvement in capacity building is pivotal in promoting Thailand as a leading bio-economy hub in the region.

\section{Malaysia}

As one of the largest shareholders of the Southeast Asia's fossil fuel resources, the total primary energy supplies in Malaysia are mainly derived from fossil fuel-based resources such as coal, oil, and gas. Statistically, the electricity consumption had increased by $138.8 \%$ from 1997 to 2017 , with a total primary energy supply of about 113 Mtoe in 2017. Out of the total primary energy supply, biofuels (i.e. biodiesel, biomass, biogas) constitute an insignificant contribution with only 702 ktoe that same year [88].

The Malaysian government had been actively engaging key public stakeholders to encourage the use of biomass for alternative energy source. In 2000, the Malaysian 
government had launched the Fifth Fuel Policy (5FP2000) that integrated renewable energy as the fifth fuel in the then Eighth Malaysian Plan from 2001 to 2005. Although the policy had focused on other sources of renewable energy such as hydropower and solar technology, biomass and biofuels were also inclusive. To complement with the 5FP2000 policy, the government had also launched the Small Renewable Energy Power (SREP) Program in 2001 to encourage the production of renewable energy by small generators and sales of generated electricity to utilities [89]. In addition, several incentives such as Investment Tax Allowance or Pioneer Status were introduced in bid to promote the use of renewable energy based on the SREP programmes in Malaysia [90]. The National Biofuel Policy 2006 (NBP 2006) was announced in 2005 to strategically position the biofuels in the transportation, industry, technologies, export, and in cleaner environment. The NBP 2006 policy served as the nation's backbone that propelled the biodiesel industry through blending of processed palm oil with petroleum diesel, as well as the production of biodiesel from the palm oil. What's more, establishments of B5 biodiesel were incepted through this policy under the overview of the MPOB [91]. Between years 2006 and 2020, a total of three Malaysia Plans, namely Ninth Malaysia Plan (9MP; 2006-2010), Tenth Malaysia Plan (10MP; 2011-2015), and Eleventh Malaysia Plan (11MP; 2016-2020), were announced with bioenergy as common key deliverables. Table 3 highlights the overall summary related to bioenergy policies and frameworks outlined in the Malaysia Plans.

Besides, in 2010, the Renewable Energy Act was initiated to implement a special tariff system as an effort to manage the renewable energy generation and guaranteed access to national grid for the participating parties [92]. Consequently, SEDA was established under the Act 726 in December 2011 to oversee the implementation of FiT by 2015 , and to ensure that the renewable energy consists of $17 \%$ of the total fuel mix by 2020 [90]. As of 2017, electricity generation by sources had shown that $16.87 \%$ was derived from the renewable energy sources, where biofuels constituted $3.02 \%$ of the total renewable energy mix [88]. In addition, the Malaysian government also introduced the National Biomass Strategy (NBS) 2020 in November 2011, which served as a blueprint for the biomass conversion (particularly oil palm biomass) to value-added downstream (i.e. bio-based chemical, bioenergy, biofuel) technologies, and to benefit the nation's economy and high-value job creation, as well as reduction in carbon emission [93]. The NBS 2020 was then revised in 2013 to expand its scope to include the biomass from forestry sector as well as dedicated crop, in order to improve the value of downstream industries [94]. Table 4 summarizes the incentives, strategies, and regulatory to further promote NBS 2020.

\section{Challenges of Biomass Energy Implementation and Mitigation: Malaysia Perspectives}

Regardless of numerous advantages of the biomass energy, abundance of the biomass sources in the country, along with the multiple initiatives by the government and respective agencies, there are several challenges for its implementation in a large scale. These challenges can be grouped into several categories, including technical, financial/economic, social, environmental impact, sustainability, and lacking in institutional/organizational issues [95-97].

Basically, slow evolution of biomass energy in Malaysia can be attributed to the technical challenges incorporating

Table 3 Highlights of the Malaysian Plans related to bioenergy policies

\begin{tabular}{|c|c|}
\hline Malaysia Plan & Policies/framework/action plans \\
\hline MP (2006-2010) & $\begin{array}{l}\text { - Initiative supports to enhance local capabilities for indigenous renewable energy-based technologies; } \\
\text { - Promotion of biofuel development using palm oil as renewable energy source of energy; } \\
\text { - Designated pump stations to supply B5-blended diesel; } \\
\text { - Improvement in accelerated capital allowance financial incentives related to renewable energy initiatives; } \\
\text { - Promotional programmes and courses to increase public awareness in energy-related management and planning }\end{array}$ \\
\hline 10MP (2011-2015) & $\begin{array}{l}\text { - New Energy Policy (2011-2015) to emphasize energy security, economic efficiency, and environmental and social } \\
\text { considerations; } \\
\text { - Mandatory blending of biofuel in transport sector; } \\
\text { - Formulation of Energy Efficiency Master Plan; } \\
\text { - Reduction in energy subsidies to achieve market pricing by } 2015\end{array}$ \\
\hline 11MP (2016-2020) & $\begin{array}{l}\text { - Electricity generation capacity via biomass, biogas, solar PV and mini-hydro are targeted to reach } 7.8 \% \text { by } 2020 \text {; } \\
\text { - Expert creations in the field of biomass, biogas, solar PV and mini-hydro through SEDA; } \\
\text { - Implementation of FiT mechanism; } \\
\text { - Improvement to biodiesel blending requirements up to } 15 \% \text { in automotive fuel via B15 programme in all sectors by } 202\end{array}$ \\
\hline
\end{tabular}


Table 4 Incentives and strategies by NBS 2020

\begin{tabular}{ll}
\hline Incentives/strategies & Remarks \\
\hline $\begin{array}{l}\text { Joint Venture clusters } \\
\text { Oil Palm Biomass Centre creation }\end{array}$ & $\begin{array}{c}\text { To alleviate risk of vertical market failure between biomass owners and downstream users } \\
\text { To accelerate the lignocellulosic conversion technologies and time-to-commercialization of bio-based } \\
\text { chemicals }\end{array}$ \\
$\begin{array}{l}\text { Pelletization Capacity Incentive } \\
\text { Pntry Point Project 6 Developing } \\
\text { Oleo Derivatives }\end{array}$ & $\begin{array}{c}\text { Provide CAPEX incentives up to 40\% to local investors to establish bio-based chemical facility } \\
\text { BioNexus Status }\end{array}$ \\
$\begin{array}{c}\text { Companies that participate in "value-added biotechnology and/or life science activities" are eligible for tax } \\
\text { breaks as well as funding application }\end{array}$ \\
Companies to receive 30\% exemption from taxable statutory income for 5 years and 100\% exemption if \\
investments are made in the specific promoted areas \\
Companies are allowed to offset 60\% of the qualifying capital expenditure incurred within 5 years against \\
Investment Tax Allowance \\
value-added production in non-promoted areas
\end{tabular}

the technological barrier as well as unavailability in technical experts [95, 98, 99]. Due to an absence in local advanced technologies, most of the technologies have been imported from the foreign countries, as such this implies high production and maintenance cost. For instance, it has been reported that the technologies for biogas production in Malaysia through the anaerobic digestion technique have been imported from the Germany [100, 101]. Moreover, lacking in the scientific and technical local expertise particularly related to technology design and construction, as well as operation and maintenance of the biomass power plants explains the low penetration of biomass energy in Malaysia. Here, limitation in local expertise is plausibly due to the lack of technical courses on bioenergy in the higher institutions [95, 102]. It is therefore imperative for the collaborative work between the Government and educational institutions to provide skill and workforce training as well as knowledge inputs to skilled personnel and human resources $[95,100]$. Besides, joint development opportunities between the countries are a good way for sharing the expertise and towards the development of bioenergy technologies, accordingly, can transform Malaysia as a bio-economy hub in the Southeast Asia region. Another technical barrier that is faced in the bioenergy deployment in Malaysia is interrelated to infrastructural barriers. Ideally, distance between the renewable energy plant and the interconnection point of the distribution system needs to be within $10 \mathrm{~km}$ distance to prevent the power loss. Nevertheless, in case of East Malaysia, the palm mills that are usually scattered in remote and sub-urban locations, and located more than $10-\mathrm{km}$ distance from the grid connection points make the whole framework infeasible, since it imparts an extremely high capital investment and caused reluctance in venturing into the biomass energy [101, 103].

The financial (or economic) barrier is amongst the common challenge faced in fostering the biomass energy in
Malaysia. Basically, the economic barrier includes several criteria including the high capital expenditure, lack of experience/trust amongst financiers and/or investors, absence in the appropriate financing scheme, and competition from fossil fuel, as well as fewer subsidies as compared to the conventional fuel [104-107]. From the Malaysian government and industry perspective, the high capital investment needed has been perceived as the greatest weakness for biomass utilization to energy production, with priority factor of 0.442 and 0.349 respectively [108]. Previously, Aghamohammadi et al. [103] reported that the capital cost needed for setting up a biogas plant in Malaysia can reach up to RM 10 million, which causes burdens to the developers due to long payback period. Herein, such huge investment can be caused by the replacement of the conventional boilers to grid-connected high-pressure boilers, and dependency on the imported equipment [107, 109]. Giulioano et al. [110] further added that the investment cost that can escalate up to $30 \%$ can be also attributed by the change in plants' location, licensingrelated costs, and/or modification of the plant design. Based on recent survey, $100 \%$ of the respondents in Sarawak agreed that high capital investment is indeed the main barrier for their active participation in biomass energy [103]. In addition, due to the high capital cost borne by developers, it is more likely that the cost will be transferred to customers, which consequentially results in an unattractiveness of this biomass energy. This is supported by Ratnasingam et al. [111] who reported that cost of producing $1 \mathrm{kWh}$ of electricity from the biomass is comparatively higher than the fossil fuel.

In terms of financial assistance, the support can be from commercial bank, Developmental Financing Institution, capital market, angel investor, and venture capital firms, as well as technology manufacturers and suppliers [112]. However, since the biomass energy industry is still low in Malaysia as compared to solar PV system, it is challenging 
to secure the potential investors for the biomass energy deployment. It has been reported that the potential investors favour a short payback period of around 2-4 years, which may not be applicable for the bioenergy plant that has higher capital cost $(\$ 1,000 / \mathrm{kW})$ compared to gas/coal power plants $(\$ 700 / \mathrm{kW})$ [113]. In addition, these financing challenges arose due to incompetency of financial institutions to evaluate loans for this business venture, apart from the limited success story of biomass energy industry to be relied upon [109]. Amran et al. [114] previously reported that the lacking in human resources with technical background in green technology projects in the financial institutions has caused them to refer to external consultants for that matter. However, these consultants sometimes do not provide the bank with reliable information, thus caused difficulties to the bank institutions. On the other hand, the financial aids are applicable for the solar PV system that has already reached the maturity stage in Malaysia thus far, where the involved banks include CIMB Sdn. Bhd. (SME Renewable Energy Financing), Alliance Bank Sdn. Bhd. (Alliance Bank Solar Financing Scheme), and United Overseas Bank (M) Sdn. Bhd. (U Solar Program), amongst others. Hence, it can be concluded that in ensuring the bankability, the developed renewable energy technologies should be proven, has high reliability, and scalable [115]. Not only that, it is reckoned that the competition with the conventional fuel also contributes to slow progress in this biomass energy. Ratnasingam et al. [116] further specified that the subsidy allocation to the fossil fuel-based energy in order to keep the price low will limit the future demand of the biomass energy. Therefore, to foster further investment in the biomass energy, provision of subsidies and incentives for the use of biomass for power generation is highly preferable [111]. Referring to Szulczyk et al. [117], the minor government subsidy will escalate the bio-generated electricity to $36.5 \%$ by 2030 , which is $16 \%$ higher as compared to bioelectricity supply in year 2016.

In context of social issues, the challenges for the biomass energy implementation are related to the market (or consumer) acceptance and community acceptance, as well as socio-political acceptance [118]. In context of consumer acceptance, the recent survey on the acceptance towards B7 biodiesel implementation in Malaysia indicates that most of the respondents in Central region of Peninsular Malaysia are aware or have heard about the biodiesel, and agreed that the biodiesel is a renewable energy; nevertheless, only few of them know about the current B7 national programme and technical know-how of the biodiesel, as well as reluctance to pay more for the biofuel [23]. Accordingly, low support of the biomass energy is plausibly due to limited knowledge on the biofuel's operation as well as the lacking in awareness $[21,119]$. Therefore, this should be addressed to ensure the successfulness of biomass energy deployment and to secure future demand. With this respects, Chin et al. [118] proposed that media plays a significant role in influencing the public acceptance. In a separate survey by Zakaria et al. [120], $93 \%$ of the respondents agreed that social media is the best platform to nurture the public awareness on the renewable energy, followed by education/school subject (69.8\%), campaign (66.2\%), and mobile apps (50\%). Thereby, an establishment of website/portal can be a kick-start in cultivating the public awareness, where the proposed contents should include the following: example of the successful biomass energy projects, update and monitoring of the biomass energy development, as well as contact information and support services. Referring to Giuliano et al. [110], some strategies that can be adopted to encourage the social acceptance towards the biomass energy include the involvement of citizens in whole stages of biomass power plants, and providing free seminars and workshop for different level of stakeholders. Besides, market acceptance should be taken into consideration as well, since the cancellation of Envo Diesel programme in Malaysia is primarily due to strong opposition from diesel engine manufacturers, despite its lower cost. Basically, the engine manufacturers claim that the palm-olein biodiesel causes clogging to engine, filter plugging, and corrosion, as well as material incompatibility; hence, they refuse to extend the warranty to vehicles that use the Envo Diesel [23, 118]. Accordingly, acceptance and support from the various stakeholders is crucial in fostering the bioenergy deployment in Malaysia.

Though the biomass energy has been perceived as a renewable and clean energy, there are also several environmental challenges included. Recently, Ghani et al. [121] reported that the ambitious Malaysian plan for the bioenergy deployment implies higher land conversion for such purposes, which affects the domestic food security and oleochemical sectors. Hassan et al. [122] mentioned that the oil palm plantation has increased by $12 \%$ within a decade, from year 2005 to 2015. Furthermore, the conversion of rainforest to agricultural plantation causes an alteration in carbon storage, as the pristine rainforest can store more carbon per hectare as compared to the agricultural plantation [123]. Specifically, it has been reported that the rainforest is capable to store up to 9.4 tonnes of $\mathrm{CO}_{2}$ per hectare per year, whereas oil palm plantation can store $\mathrm{CO}_{2}$ of only 4.0 tonnes per hectare per year [117]. In context of Malaysia, expansion of the oil palm plantation particularly for the industrial biofuel (i.e. biodiesel) production that is mainly through deforestation and peatland conversion has caused a significant emission of GHGs to the atmosphere, including $\mathrm{CO}_{2}$ and nitrous oxides $\left(\mathrm{N}_{2} \mathrm{O}\right)$ [22]. Referring to the recent work by Kusin et al. [124], large-scale converted land use produces about $6.47-7.78 \mathrm{~kg} \mathrm{~N}_{2} \mathrm{O}-\mathrm{N} / \mathrm{ha}$, whereas small-scale converted land use and logged-over forest into the oil palm plantation produce 6.49-7.85 kg N $\mathrm{N}_{2} \mathrm{O}-\mathrm{N} / \mathrm{ha}$ and 6.58-7.75 kg N $\mathrm{N}_{2} \mathrm{O}-\mathrm{N} / \mathrm{ha}$, respectively. Basically, $\mathrm{N}_{2} \mathrm{O}$ emission is mostly contributed 
by the use of fertilizer for the plant's growth [125, 126], which contributes to acid rain as well as the eutrophication problems that lead to depletion of oxygen in both lakes and rivers [127]. In terms of application, it is reported that the biodiesel blend will emit more nitrogen oxides compared to conventional diesel, due to presence of high oxygen contents that favour the combustion process [128, 129]. Further, since Malaysia has been perceived to have the highest deforestation rate in the world with estimated loss of $14.4 \%$ of total forest vegetation [91, 130], the biodiversity of ecosystem has been greatly endangered. Referring to Lim and Teong [22], extinction of Orang Utan has been frequently highlighted by the environmentalists (The Orangutan Project). Due to these environmental drawbacks of deforestation activities, non-governmental organizations have addressed the need to enhance the biofuel yield in smallholder production, instead of expansion of the oil palm plantation area [131]. Even so, sustainable practices as well as check and balance between the bioenergy production as well as the resources consumption are advocated to reduce the environmental threats. Moreover, the bioenergy production that requires a copious amount of water for the feedstock production and fuel refining is one of the barriers for the bioenergy deployment, given some regions in the country suffer from water scarcity $[29,132]$. In fact, Wu et al. [125] reported that the environmental consequences caused by the bioenergy production are closely related to the water resources and pollution $(16 \%)$, followed by the greenhouse gas emission (6\%) and biodiversity and soil organic carbon (5\%), as well as soil erosion issues $(0.8 \%)$. The food-water-energy nexus continues to play a significant role in ensuring the successfulness of bioenergy programme in Malaysia. Accordingly, a life cycle analysis (LCA) is a practical approach to assess the environmental consequences of the biomass energy production.

In terms of the biogas production that is typically being produced via landfilling process, odour pollution problems have become the major barrier, which negatively influences both physical and mental e.g. health conditions and bad experiences. This is verified by the recent survey to local residents in Perlis who located within the vicinity of landfill area, where the findings show that the respondents within 0-2 km radius did experience the health effects as well as disturbance in their daily lives [133]. Further, another environmental concern related to the biogas production is related to landfill gas (i.e. methane) diffusion to the atmosphere through the pressure difference, crack, landfill cover, and surrounding topsoils. The emission of these gases then leads to safety risk due to potential explosion risk and to aggravate the global warming problems [133]. Accordingly, installation of spatial and a temporal high-resolution monitoring networks is a preferable mitigation route since the emission of the hazardous gases to surroundings is realistically monitored and allows for an early protection and troubleshooting.
The sustainability challenge of the bioenergy industry is mainly related to the feedstock availability for the sufficient supply. In this sense, to ensure sustainable biomass supply for the bioenergy production, high-yield, high-quality, and low-cost biomass needs to be immediately produced [134]. Hence, valorization of the various types of biomass materials for the bioenergy production is significant in ensuring the long-term development of the biomass energy sector in Malaysia. Such strategy is significant since an over-dependency on single feedstock may cause feedstock limitation issues, and thus hampers the large-scale bioenergy deployment [22]. For instance, the biodiesel production in Malaysia that strongly depends on the palm waste availability has the tendency to increase the market price of crude palm oil, which in turn results in infeasibility of the biomass energy production. In fact, for the bio-refinery plant with a capacity of $0-15,000$ tons per day, more than $2,000-5,000$ tons biomass daily is required for the process to be economical $\left(\$ 850-875 / \mathrm{m}^{3}\right)$ [135]. The biomass availability issue is aggravated by the fact that $80 \%$ of the mill operators utilize about $40 \%$ of the biomass for animal feed, mulching, composting, and soil conditioning purposes [136]. Moreover, the biomass supply to the bio-refinery plants may be worsen by the logistic barriers related to collection, transportation, and storage of these biomass sources. Referring to Ghani et al. [121], the tanker lorries owned by the private mills have low capacity that ranges from 15 to 25 tonnes each. Thus, for the mills that produce about 170 tonnes crude palm oil in a day, lots of tanker lorries and/or multiple trips from mill to the refinery plant will be expected, which is considered impractical. The impracticality here is attributed by two key parameters - transportation cost as well as $\mathrm{CO}_{2}$ emission. Salleh et al. [137] reported that the standard rate for a lorry to deliver 10 metric tons of biomass is varied: RM 200 for distance less than $30 \mathrm{~km}, \mathrm{RM} 300$ for distance in between 300 and $500 \mathrm{~km}$, and RM 500 for distance beyond $500 \mathrm{~km}$. Further, consumption of a gallon diesel fuel for 5.9-mile travel (equivalent to $9.5 \mathrm{~km}$ ) emits 0.0002 metric tons $\mathrm{CO}_{2}$ to the atmosphere $[137,138]$. Fadzil et al. [95] thus recommended that a careful planning by the stakeholders is crucial in ensuring the sufficiency of these biomass supplies to all the large-scale plants. Furthermore, implementation of an on-site generation is worthy to reduce the logistic barrier as well as reduction in biomass mobilization costs, as has been done in the Netherlands [136].

Based in "Biomass Energy-Related Environmental Policy", all the countries have made excellent progress in the establishment of bioenergy-related policies and frameworks. However, regardless of having several key policies in place, progresses and developments in production of bioenergy are still hindered especially in the Southeast countries, including Malaysia. Therefore, in this context, lacking in the institutional/organization presumably contributes to poor 
execution of these policies and slow progression of biomass energy in Malaysia. Ideally, governance authorities play a bigger role in overseeing these managements and developments, and to prevent miscommunications between stakeholders, subsequently to drive the transformation towards the biomass energy programmes. Despite having numerous institutional and organizational bodies in bioenergy sector in Malaysia (i.e. government agencies, industry players, non-governmental organizations) including the Ministry of Energy and Natural Resources, Economic Planning Unit, Malaysia Biomass Industry Confederation, etc., the lack of coordination amongst these groups will in turn result in failure of the bioenergy. Thus, to compete with other emerging countries that are increasingly reliant to the renewable bioenergy resources, both Malaysian government and relevant stakeholders should come into an agreement and a strategic planning and to reconsider the biofuel's role in future.

\section{Conclusions}

Due to multiple benefits of bioenergy that are particularly related to the climate change mitigation, improvement in energy security, and rural development, it is undeniable that this biomass energy can boost up Malaysia's renewable energy sector in the future. Besides, the bioenergy development in the country is supported by the increasing abundance of biomass, particularly oil palm biomass that has the potential to be converted to the alternative and sustainable energy. From the analysis, several insights have been drawn: first, despite government efforts in promoting the bioenergy market and use via policy formulation and incentives, there are still barriers that hinder the market penetration. In addition, compared to other regions, carbon tax and pricings had not gained significant traction in the Asian countries and cause discouragement to industry players in championing the biomass-related renewable energy production. Second, there are also limitation in technology and technical experts, high capital expenditure, limitation in financial assistance, lack of knowledge and awareness of the public, and opposition and reluctance of the market developers, as well as associated environmental challenges due to deforestation and greenhouse gas emission from the manufacturing process. With regard to these challenges, it is anticipated for the Malaysian primary stakeholder in energy-related to find optimal solutions and further strengthen the bioenergy sector. Overall, the review of bioenergy in Malaysia is promising as the database provided i.e. challenges for an effective implementation, can serve as a guideline to the researchers and industry players in going forward and expanding the bioenergy sector further.
Acknowledgements The authors would like to acknowledge the Ministry of Higher Education Malaysia for providing the support and awarding the Higher Institution of Centre of Excellence (HICoE) status to the Centre of Biofuel and Biochemical, Universiti Teknologi PETRONAS.

Funding This work has been funded by the Ministry of Higher Education Malaysia (grant no. 015MA0-052).

Data Availability All data generated or analysed during this study are included in this review article.

Code Availability Not applicable.

\section{Declarations}

Ethics Approval and Consent to Participate Not applicable.

Consent for Publication Not applicable.

Competing Interests The authors declare no competing interests.

\section{References}

1. Haiges R, Wang Y, Ghoshray A, Roskilly A (2017) Optimization of Malaysia's power generation mix to meet the electricity demand by 2050. Energy Procedia 142:2844-2851

2. Malaysia Energy Statistics Handbook 2018 (2018) Suruhanjaya Tenanga (Energy Commision). Putrajaya, Malaysia

3. Latif SNA, Chiong MS, Rajoo S, Takada A, Chun Y-Y, Tahara $\mathrm{K}$, Ikegami Y (2021) The trend and status of energy resources and greenhouse gas emissions in the Malaysia power generation mix. Energies 14(8):1-26

4. Renewable capacity highlights (2020)

5. Tock JY, Lai CL, Lee KT, Tan KT, Bhatia S (2010) Banana biomass as potential renewable energy resource: a Malaysian case study. Renew Sustain Energy Rev 14(2):798-805

6. Abdullah WSW, Osman M, Kadir MZAA, Verayiah R (2019) The potential and status of renewable energy development in Malaysia. Energies 12:2437

7. Yadav VG, Yadav GD, Patankar SC (2020) The production of fuels and chemicals in the new world: critical analysis of the choice between crude oil and biomass vis-à-vis sustainability and the environment. Clean Technol Environ Policy:1-18

8. Stougie L, Giustozzi N, van der Kooi H, Stoppato A (2018) Environmental, economic and exergetic sustainability assessment of power generation from fossil and renewable energy sources. Int J Energy Res 42(9):2916-2926

9. Ozturk M, Saba N, Altay V, Iqbal R, Hakeem KR, Jawaid M, Ibrahim FH (2017) Biomass and bioenergy: an overview of the development potential in Turkey and Malaysia. Renew Sustain Energy Rev 79:1285-1302

10. Nansaior A, Patanothai A, Rambo AT, Simaraks S (2013) The sustainability of biomass energy acquisition by households in urbanizing communities in Northeast Thailand. Biomass Bioenerg 52:113-121

11. Suzuki K, Tsuji N, Shirai Y, Hassan MA, Osaki M (2017) Evaluation of biomass energy potential towards achieving sustainability in biomass energy utilization in Sabah, Malaysia. Biomass Bioenerg 97:149-154 
12. Jafri N, Jimat D, Azmin N, Sulaiman S, Nor Y The potential of biomass waste in Malaysian palm oil industry: a case study of Boustead Plantation Berhad. IOP Conference Series: Materials Science and Engineering, 2021. vol 1. IOP Publishing, p 012028

13. Riayatsyah TMI, Ong HC, Chong WT, Aditya L, Hermansyah H, Mahlia TMI (2017) Life cycle cost and sensitivity analysis of Reutealis trisperma as non-edible feedstock for future biodiesel production. Energies 10(7):877

14. Yusuf N, Kamarudin SK, Yaakub Z (2011) Overview on the current trends in biodiesel production. Energy Convers Manage 52(7):2741-2751

15. Nomanbhay S, Hussein R, Ong MY (2018) Sustainability of biodiesel production in Malaysia by production of bio-oil from crude glycerol using microwave pyrolysis: a review. Green Chem Lett Rev 11(2):135-157

16. Li L, Loo BP (2014) Alternative and transitional energy sources for urban transportation. Curr Sustain/Renew Energy Rep 1(1):19-26

17. Gan PY, Li ZD (2014) Econometric study on Malaysia's palm oil position in the world market to 2035. Renew Sustain Energy Rev 39:740-747

18. Tan YH, Abdullah MO, Kansedo J, Mubarak NM, San Chan Y, Nolasco-Hipolito C (2019) Biodiesel production from used cooking oil using green solid catalyst derived from calcined fusion waste chicken and fish bones. Renew Energy 139:696-706

19. Anuar MR, Abdullah AZ (2016) Challenges in biodiesel industry with regards to feedstock, environmental, social and sustainability issues: a critical review. Renew Sustain Energy Rev 58:208-223

20. Chin M (2011) Biofuels in Malaysia: an analysis of the legal and institutional framework, vol 64. CIFOR

21. Masjuki H, Kalam M, Mofijur M, Shahabuddin M (2013) Biofuel: policy, standardization and recommendation for sustainable future energy supply. Energy Procedia 42:577-586

22. Lim S, Teong LK (2010) Recent trends, opportunities and challenges of biodiesel in Malaysia: an overview. Renew Sustain Energy Rev 14(3):938-954

23. Mohammed K Consumer perceptions on the implementation of biodiesel in the transport sector: a case in the Central Region of Peninsular Malaysia. Oil Palm Ind Econ J 16(2):1-8

24. Aditiya H, Mahlia TMI, Chong W, Nur H, Sebayang A (2016) Second generation bioethanol production: a critical review. Renew Sustain Energy Rev 66:631-653

25. Hassan MH, Kalam MA (2013) An overview of biofuel as a renewable energy source: development and challenges. Procedia Eng 56:39-53

26. Tye YY, Lee KT, Abdullah WNW, Leh CP (2011) Second-generation bioethanol as a sustainable energy source in Malaysia transportation sector: status, potential and future prospects. Renew Sustain Energy Rev 15(9):4521-4536

27. Chanthawong A, Dhakal S (2016) Liquid biofuels development in Southeast Asian countries: an analysis of market, policies and challenges. Waste Biomass Valorization 7(1):157-173

28. Kumar S, Shrestha P, Salam PA (2013) A review of biofuel policies in the major biofuel producing countries of ASEAN: production, targets, policy drivers and impacts. Renew Sustain Energy Rev 26:822-836

29. Elder M, Hayashi S (2018) A regional perspective on biofuels in Asia. Biofuels and Sustainability. Springer, pp 223-246

30. Szulczyk KR, Ziaei SM, Zhang C (2021) Environmental ramifications and economic viability of bioethanol production in Malaysia. Renew Energy 172:780-788

31. Szulczyk K, Yap C, Ho P (2021) The economic feasibility and environmental ramifications of biodiesel, bioelectricity, and bioethanol in Malaysia. Energy Sustain Dev 61:206-216
32. Shafie SM, Othman Z, Hami N, Omar S (2020) The potential of using biogas feeding for fuel cells in Malaysia. Int J Energy Econ Policy 10(1):109

33. Bong CPC, Ho WS, Hashim H, Lim JS, Ho CS, Tan WSP, Lee CT (2017) Review on the renewable energy and solid waste management policies towards biogas development in Malaysia. Renew Sustain Energy Rev 70:988-998

34. Hoo PY, Hashim H, Ho WS (2018) Opportunities and challenges: landfill gas to biomethane injection into natural gas distribution grid through pipeline. J Clean Prod 175:409-419

35. Yong ZJ, Bashir MJ, Ng CA, Sethupathi S, Lim JW, Show PL (2019) Sustainable waste-to-energy development in Malaysia: appraisal of environmental, financial, and public issues related with energy recovery from municipal solid waste. Processes $7(10): 676$

36. Loh S, Nasrin A, Mohamad Azri S, Nurul Adela B, Muzzammil N (2017) Biogas capture-a means of reducing greenhouse gas emissions from palm oil mill effluent. Oil Palm Bulletin 75:27-36

37. Aziz NIHA, Hanafiah MM, Gheewala SH (2019) A review on life cycle assessment of biogas production: challenges and future perspectives in Malaysia. Biomass Bioenerg 122:361-374

38. Loh S, Nasrin A, Azri SM, Adela BN, Muzzammil N, Jay TD, Eleanor RS, Lim W, Choo Y, Kaltschmitt M (2017) First Report on Malaysia's experiences and development in biogas capture and utilization from palm oil mill effluent under the Economic Transformation Programme: current and future perspectives. Renew Sustain Energy Rev 74:1257-1274

39. Yusoff MHM, Ayoub M, Hamza Nazir M, Zahid I, Ameen M, Abbas W, Shoparwe NF, Abbas N (2021) Comprehensive review on biodiesel production from palm oil mill effluent. ChemBioEng Rev 8(5):439-462

40. Choong YY, Chou KW, Norli I (2018) Strategies for improving biogas production of palm oil mill effluent (POME) anaerobic digestion: a critical review. Renew Sustain Energy Rev 82:2993-3006

41. Mah AXY, Ho WS, Bong CPC, Hassim MH, Liew PY, Asli UA, Kamaruddin MJ, Chemmangattuvalappil NG (2019) Review of hydrogen economy in Malaysia and its way forward. Int J Hydrogen Energy 44:661-5675

42. Kayfeci M, Keçebaş A, Bayat M (2019) Hydrogen production. Solar Hydrogen Production. Elsevier, pp 45-83

43. Alam MNHZ, Adrus N, Wahab MFA, Kamaruddin MJ, Sani MH (2020) Utilization of agro-waste as carbon source for biohydrogen production: prospect and challenges in Malaysia. Valorisation of agro-industrial residues-Volume I: biological approaches. Springer, pp 131-147

44. Hossain MA, Jewaratnam J, Ganesan P (2016) Prospect of hydrogen production from oil palm biomass by thermochemical process-a review. Int J Hydrogen Energy 41(38):16637-16655

45. Ni M, Leung DY, Leung MK, Sumathy K (2006) An overview of hydrogen production from biomass. Fuel Process Technol 87(5):461-472

46. Kalinci Y, Hepbasli A, Dincer I (2009) Biomass-based hydrogen production: a review and analysis. Int J Hydrogen Energy 34(21):8799-8817

47. Chan YH, Cheah KW, How BS, Loy ACM, Shahbaz M, Singh HKG, Shuhaili AFA, Yusup S, Ghani WAWAK, Rambli J (2019) An overview of biomass thermochemical conversion technologies in Malaysia. Sci Total Environ 680:105-123

48. Dou B, Zhang H, Song Y, Zhao L, Jiang B, He M, Ruan C, Chen $\mathrm{H}, \mathrm{Xu}$ Y (2019) Hydrogen production from the thermochemical conversion of biomass: issues and challenges. Sustain Energy Fuels 3(2):314-342 
49. Nikolaidis P, Poullikkas A (2017) A comparative overview of hydrogen production processes. Renew Sustain Energy Rev 67:597-611

50. Aziz M, Darmawan A, Juangsa FB (2021) Hydrogen production from biomasses and wastes: a technological review. Int J Hydrogen Energy 46(68):33756-33781

51. IEA Bioenergy Countries' Report - Update 2018 (2018) IEA Bioenergy

52. Helynen S (2004) Bioenergy policy in Finland. Energy Sustain Dev 8(1):36-46

53. Ericsson K, Huttunen S, Nilsson LJ, Svenningsson P (2004) Bioenergy policy and market development in Finland and Sweden. Energy Policy 32:1707-1721

54. Tamminen E, Nousiainen I (1997) Bioenergian edistäminen ja sen tuloksellisuus Suomessa [The Finnish policy for the promotion of bioenergy and its results]. Ministry of Trade and Industry, Studies and reports, Helsinki

55. Berg A, Lukkarinen J, Ollikka K (2020) 'Sticky' policies-three country cases on long-term commitment and rooting of RE policy goals. Energies 13(6):1351

56. Åkerman M, Kilpiö A, Peltola T (2010) Institutional change from the margins of natural resource use: the emergence ofsmall-scale bioenergy production within industrial forestry in Finland. Forest Policy Econ 12:181-188

57. Albrecht M, Kortelainen J, Sawatzky M, Lukkarinen J, Rytteri T (2017) Translating bioenergy policy in Europe: mutation, aims and boosterism in EU energy governance. Geoforum 87:73-84

58. Lindstad BH, Pistorius T, Ferranti F, Dominguez G, GorrizMifsud E, Kurttila M, Leban V, Navarro P, Peters DM, Pezdevsek Malovrh S, Prokofieva I, Schuck A, Solberg B, Viiri H, Zanik Stirn L, Krc J (2015) Forest-based bioenergy policies in five European countries: an explorative study of interactions withnational and EU policies. Biomass Bioenerg 80:102-113

59. Database IIRP (2019) National Energy and Climate Strategy of Finland for 2030

60. Finland - 2018 Update (2018)

61. A policy framework for climate and energy in the period from 2020 to 2030 (2014). Brussels

62. Proposal for a Regulation of the European Parliament and of the Council on the inclusion of greenhouse gas emissions and removals from land use, land use change and forestry into the 2030 climate and energy framework and amending Regulation No 525/2013 of (2016). Brussels

63. A new EU Forest Strategy: for forests and the forest-based sector (2013). Brussels

64. Proskurina S, Sikkema R, Heinimö J, Vakkilainen E (2016) Five years left - how are the EU member states contributing to the $20 \%$ target for EU's renewable energy consumption; the role of woody biomass. Biomass Bioenerg 95:64-77

65. Sweden - 2018 update (2018) IEA Bioenergy

66. Energipolitikens inriktning (2017/18) Ministry of the Environment and Energy

67. Berlina A, Mikkola N (2017) Bioenergy development in Finland and Sweden: the cases of North Karelia, Jämtland, and Västernorrland. Nordregio, Stockholm, Sweden

68. Mikkola N, Randall L, Hagberg A Green Highway linking Östersund and Trondheim. Green growth in Nordic regions - 50 ways to make it happen Nordregio, Stockholm, Sweden, pp 84

69. de Jong J, Akselsson C, Berglund H, Egnell G, Gerhardt K, Lönnberg L, Olsson B, von Stedingk H (2014) Consequences of an increased extraction of forest biofuels in Sweden - a synthesis from the biofuel research programme 2007-2011. The Swedish Energy Agency

70. Global energy statistical yearbook 2011. Total Energy Consumption (2011)

71. Blueprint Pengelolaan Energy Nasional 2006-2025 (2006). Departemen Energi dan Sumber Daya Mineral Republik Indonesia, Jakarta

72. Mujiyanto S, Tiess G (2013) Secure energy supply in 2025: Indonesia's need for an energy policy strategy. Energy Policy 61:31-41

73. Putrasari Y, Praptijanto A, Santoso WB (2016) Resources, policy, and research activities of biofuel in Indonesia: a review. Energy Rep 2:237-245

74. Kharina A, Malins C, Searle S (2016) Biofuels policy in Indonesia: overview and status report The International Council on Clean Transportation, Washington, DC

75. Indonesian Oil Palm Statistics 2014 (2015)

76. Naimah D, Morgunova M Analysis of palm-oil-based biodiesel in Indonesia using technological innovation system approach. ASTECHNOVA 2017, Yogyakarta, 2018

77. Hit by oil crash, Indonesia set to delay B40 biodiesel, stay with B30 for now. (2020)

78. Singh R, Setiawan AD (2013) Biomass energy policies and strategies: harvesting potential in India and Indonesia. Renew Sustain Energy Rev 22:332-345

79. Jatuporn C, Sukprasert P, Chulaphan W, Sriariyawat S (2016) Assessing the impact of exchange rate on major agricultural export commodities of Thailand. Int J Agric Technol 12(6):973-982

80. Pipitpukdee S, Attavanich W, Bejranonda S (2020) Climate change impacts on sugarcane production in Thailand. Atmosphere 11(4):408

81. Nidhiprabha B (2019) Commodity price cycles, the agricultural trap, and Thailand's incessant subsidies. Asian Econ Pap 18(2):49-69

82. Precharjarn S, Prasertsri P (2010) Thailand biofuels annual 2010. USDA Foreign Agricultural Services

83. Wattana S (2014) Bioenergy development in Thailand: challenges and strategies. 2013 International Conference on Alternative Energy in Developing Countries and Emerging Economies, Bangkok, Thailand

84. Nupueng S, Oosterveer P, Mol APJ (2018) Implementing a palm oil-based biodiesel policy: the case of Thailand. Energy Sci Eng 6(6):643-657

85. Permpool N, Bonnet S, Gheewala SH (2016) Greenhouse gas emissions from land use change due to oil palm expansion in Thailand for biodiesel production. J Clean Prod 134(Part B):532-538

86. Renewable Energy Outlook Thailand (2017). International Renewable Energy Agency, Abu Dhabi

87. Fielding M, Aung MT (2018) Bioeconomy in Thailand: a case study. Stockholm Environment Institute, Stockholm, Sweden

88. Malaysia Key Energy Statistics, 2018 (2018)

89. Oh TH, Chua SC (2010) Energy efficiency and carbon trading potential in Malaysia. Renew Sustain Energy Rev 14(7):2095-2103

90. Hashim H, Ho WS (2011) Renewable energy policies and initiatives for a sustainable energy future in Malaysia. Renew Sustain Energy Rev 15(9):4780-4787 
91. Johari A, Nyakuma BB, Nor SHM, Mat R, Hashim H, Ahmad A, Zakaria ZY, Abdullah TAT (2015) The challenges and prospects of palm oil based biodiesel in Malaysia. Energy 81:255-261

92. Petinrin JO, Shaaban M (2015) Renewable energy for continuous energy sustainability in Malaysia. Renew Sustain Energy Rev 50:967-981

93. National Biomass Strategy 2020: new wealth creation for Malaysia's palm oil industry (2011)

94. National Biomass Strategy 2020: new wealth creation for Malaysia's biomass industry (Version 2.0, 2013) (2013)

95. Fadzil NHM, Chen GK, Hwang GH (2016) Challenges of biomass energy implementation in Malaysia. Medwell $\mathrm{J}$ 11:2910-915

96. Chung JN (2013) Grand challenges in bioenergy and biofuel research: engineering and technology development, environmental impact, and sustainability. Front Energy Res 1:4

97. Xu CC, Liao B, Pang S, Nazari L, Mahmood N, Tushar MS, Dutta A, Ray MB (2018) 1.19 Biomass Energy. Cellulose 40:50

98. How BS, Ngan SL, Hong BH, Lam HL, Ng WPQ, Yusup S, Ghani WAWAK, Kansha Y, Chan YH, Cheah KW (2019) An outlook of Malaysian biomass industry commercialisation: perspectives and challenges. Renew Sustain Energy Rev 113:109277

99. Lim S, Lee KT (2012) Implementation of biofuels in Malaysian transportation sector towards sustainable development: a case study of international cooperation between Malaysia and Japan. Renew Sustain Energy Rev 16(4):1790-1800

100. Nevzorova T, Kutcherov V (2019) Barriers to the wider implementation of biogas as a source of energy: a state-of-the-art review. Energy Strat Rev 26:100414

101. Kumaran P, Hephzibah D, Sivasankari R, Saifuddin N, Shamsuddin AH (2016) A review on industrial scale anaerobic digestion systems deployment in Malaysia: opportunities and challenges. Renew Sustain Energy Rev 56:929-940

102. Yatim P, Lin NS, Lam HL, Choy EA (2017) Overview of the key risks in the pioneering stage of the Malaysian biomass industry. Clean Technol Environ Policy 19(7):1825-1839

103. Aghamohammadi N, Reginald SS, Shamiri A, Zinatizadeh AA, Wong LP, Sulaiman N, Binti NM (2016) An investigation of sustainable power generation from oil palm biomass: a case study in Sarawak. Sustainability 8(5):416

104. Moorthy K, Patwa N, Gupta Y (2019) Breaking barriers in deployment of renewable energy. Heliyon 5(1):e01166

105. Yuosoff S, Kardooni R Barriers and challenges for developing RE policy in Malaysia. International conference on future environment and energy IPCBEE, 2012

106. Zahraee SM, Assadi MK (2006) Applications and challenges of the palm biomass supply chain in Malaysia. ARPN J Eng Appl Sci 12(20):789-5793

107. Hamzah N, Tokimatsu K, Yoshikawa K (2019) Solid fuel from oil palm biomass residues and municipal solid waste by hydrothermal treatment for electrical power generation in Malaysia: a review. Sustainability 11(4):1060

108. Darshini D, Dwivedi P, Glenk K (2013) Capturing stakeholders views on oil palm-based biofuel and biomass utilisation in Malaysia. Energy Policy 62:1128-1137

109. Sulaiman O, Saharuddin A, Nik W (2011) Potential of waste based biomass cogeneration for Malaysia energy sector. Kuwait Chapter of Arabian Journal of Business and Management Review 33(832):1-25

110. Giuliano A, Gioiella F, Sofia D, Lotrecchiano N (2018) A novel methodology and technology to promote the social acceptance of biomass power plants avoiding nimby syndrome. Chem Eng Trans 67:307-312

111. Ratnasingam J, Ramasamy G, Ioras F, Senin AL (2017) Environmental and economic impact of using logging residues as bioenergy: the case of Malaysia. BioResources 12(4):7268-7282

112. Nyakuma BB (2018) Biomass energy outlook in Malaysia using functions of innovation systems

113. Sims RE (2002) The brilliance of bioenergy: in business and in practice. Earthscan

114. Amran A, Nejati M, Ooi SK, Darus F (2018) Exploring issues and challenges of green financing in Malaysia: perspectives of financial institutions. Sustainability and Social Responsibility of Accountability Reporting Systems. Springer, pp 255-266

115. Yatim P, Ngan L, Lam HL (2017) Financing green growth in Malaysia: enabling conditions and challenges. Chem Eng Trans 61:1579-1584

116. Ratnasingam J, Ramasamy G, Wai LT, Senin AL, Muttiah N (2015) The prospects of rubberwood biomass energy production in Malaysia. BioResources 10(2):2526-2548

117. Szulczyk KR, Cheema MA, Cullen R, Khan AR (2019) Bioelectricity in Malaysia: economic feasibility, environmental and deforestation implications. Aust J Agric Resour Econ 64(2):94-321

118. Chin H-C, Choong W-W, Alwi SRW, Mohammed AH (2014) Issues of social acceptance on biofuel development. J Clean Prod 71:30-39

119. Radics RI, Dasmohapatra S, Kelley SS (2016) Public perception of bioenergy in North Carolina and Tennessee. Energy Sustain Soc 6(1):17

120. Zakaria S, Basri S, Kamarudin SK, Majid NAA public awareness analysis on renewable energy in Malaysia. IOP Conference Series: Earth and Environmental Science, ate 2019. vol 1. IOP Publishing, p 012105

121. Ghani WWAK, Salleh M, Adam S, Shafri HM, Shaharum S, Lim K, Rubinsin N, Lam H, Hasan A, Samsatli S (2019) Sustainable bio-economy that delivers the environment-food-energy-water nexus objectives: the current status in Malaysia. Food Bioprod Process 118:167-186

122. Hassan MA, Ahmad Farid MA, Shirai Y, Ariffin H, Othman MR, Samsudin MH, Hasan MY (2019) Oil palm biomass biorefinery for sustainable production of renewable materials. Biotechnol $\mathrm{J}$ 14(6): 1800394

123. Szulczyk KR, Khan MAR (2018) The potential and environmental ramifications of palm biodiesel: evidence from Malaysia. J Clean Prod 203:260-272

124. Kusin FM, Akhir NIM, Mohamat-Yusuff F, Awang M (2017) Greenhouse gas emissions during plantation stage of palm oilbased biofuel production addressing different land conversion scenarios in Malaysia. Environ Sci Pollut Res 24(6):5293-5304

125. Wu Y, Zhao F, Liu S, Wang L, Qiu L, Alexandrov G, Jothiprakash V (2018) Bioenergy production and environmental impacts. Geoscience Lett 5(1):14

126. Ravindranath N, Lakshmi CS, Manuvie R, Balachandra P (2011) Biofuel production and implications for land use, food production and environment in India. Energy Policy 39(10):5737-5745

127. Faizal M, Ateeb S (2018) Energy, economic and environmental impact of palm oil biodiesel in Malaysia. J Mech Eng Res Dev 41(3):93-95

128. Radhakrishnan S, Devarajan Y, Mahalingam A (2017) Emissions analysis on diesel engine fueled with palm oil biodiesel and pentanol blends. J Oil Palm Res 29(3):380-386

129. Abed K, Gad M, El Morsi A, Sayed M, Elyazeed SA (2019) Effect of biodiesel fuels on diesel engine emissions. Egypt J Pet 28(2):183-188 
130. Nadarajah KK (2018) Biofuel sector in Malaysia: challenges and future prospects. Biofuels: Greenhouse Gas Mitigation and Global Warming. Springer, pp 177-192

131. Padfield R, Drew S, Syayuti K, Page S, Evers S, Campos-Arceiz A, Kangayatkarasu N, Sayok A, Hansen S, Schouten G (2016) Landscapes in transition: an analysis of sustainable policy initiatives and emerging corporate commitments in the palm oil industry. Landsc Res 41(7):744-756

132. Ahmed F, Siwar C, Begum RA (2014) Water resources in Malaysia: issues and challenges. J Food Agric Environ 12(2):1100-1104

133. Izhar TNT, Ibrahim NM, Mokthi NA (2012) A study on odour nuisance near open dump landfill. J Eng Res Educ 6:97-104

134. Ahorsu R, Medina F, Constantí M (2018) Significance and challenges of biomass as a suitable feedstock for bioenergy and biochemical production: a review. Energies 11(12):3366

135. Balan V (2014) Current challenges in commercially producing biofuels from lignocellulosic biomass. ISRN Biotechnology 2014
136. Umar MS, Jennings P, Urmee T (2014) Sustainable electricity generation from oil palm biomass wastes in Malaysia: an industry survey. Energy 67:496-505

137. Salleh SF, Rahman AA, Abdullah TART (2018) Potential of deploying empty fruit bunch (EFB) for biomass cofiring in Malaysia's largest coal power plant. 2018 IEEE 7th International Conference on Power and Energy (PECon). IEEE, pp 429-433

138. Salleh SF, Gunawan MF, Zulkarnain MFB, Halim A (2019) Modelling and optimization of biomass supply chain for bioenergy production. J Environ Treat Tech 7(4):689-695

Publisher's Note Springer Nature remains neutral with regard to jurisdictional claims in published maps and institutional affiliations. 